University of Nebraska - Lincoln

DigitalCommons@University of Nebraska - Lincoln

Textile Society of America Symposium

Proceedings

Textile Society of America

$10-2020$

Between Craft and Design: Lucienne Day and Eszter Haraszty

Kevin Kosbab

Follow this and additional works at: https://digitalcommons.unl.edu/tsaconf

Part of the Art and Materials Conservation Commons, Art Practice Commons, Fashion Design Commons, Fiber, Textile, and Weaving Arts Commons, Fine Arts Commons, and the Museum Studies Commons

This Article is brought to you for free and open access by the Textile Society of America at DigitalCommons@University of Nebraska - Lincoln. It has been accepted for inclusion in Textile Society of America Symposium Proceedings by an authorized administrator of DigitalCommons@University of Nebraska - Lincoln. 


\section{Between Craft and Design: Lucienne Day and Eszter Haraszty Kevin Kosbab kevin@feeddog.net}

Professionally, I am a maker and designer of quilts, but my interest in mid-century modern design predates learning to sew. My quilts have thus drawn inspiration from the mid-century graphic, industrial, and other designers I admired. I have since sought out deeper, direct connections between those designers and quiltmaking and other needlework, which has led me to the two designers I discuss in this paper. The professional biographies of Lucienne Day and Eszter Haraszty show some definite similarities. Born only three years apart-Day in 1917 in England, and Haraszty in 1920 in Hungary - each studied at art college before embarking on careers that would make them leaders in both the design and business of mid-century textiles. Following her epoch-defining Calyx print showcased at the Festival of Britain (1951), Day received prominent commissions with Heal Fabrics and other firms in Britain for more than two decades. In the United States, Haraszty was appointed director of the textile division at Knoll, the highly influential mid-century design. Later, each designer turned her talents away from commercial production and toward needlework-derived textile art.

Yet their methods and attitudes toward their needlework were strikingly different. Both designers' commercial work is well documented in scholarly design literature (Day's especially ${ }^{1}$ ), though their needlework is relatively neglected. But the period in which they produced this needlework was a time of debate about the roles and relative merits of artists, craftspeople, and industrial designers. In this paper, I aim to contextualize Day's and Haraszty's textile art, especially to show how the divergent stories they told through and about needlework reflect debate within the solidifying studio craft movement, as well as the tension between critical perspectives of "women's work" as alternately oppressive or liberating.

As women growing up in Europe in the early twentieth century, Day and Haraszty were taught sewing and needlework skills long before they entered art school, whether they liked it or not. Haraszty reminisced with characteristic wit, "Our teachers were no different than those of any other country in their insistence that every little girl had to learn sewing if she wanted to grow up to be a good woman. At six, I was not at all sure that I wished to grow up to be a woman, let alone a good one." 2 Though she didn't make peace with embroidery until much later in life, she did construct clothing to her own design in her school years. ${ }^{3}$ Amid her professional demands, Day knitted clothes, sewed curtains, and even made a patchwork quilt made from her dresses. ${ }^{4}$

\footnotetext{
${ }^{1}$ Most notably, two monographs: Lesley Jackson, Robin \& Lucienne Day: Pioneers of Modern Design (New York: Princeton Architectural Press, 2001); and Andrew Casey, Lucienne Day: In the Spirit of the Age (Woodbridge, Suffolk: Antique Collectors' Club, 2014).

${ }^{2}$ Eszter Haraszty and Bruce David Colen, Needlepainting: A Garden of Stitches (New York: Liveright, 1974$), 1$.

${ }^{3}$ Earl Martin, "Eszter Haraszty (1920-1994)," in Knoll Textiles, 1945-2010, ed. Earl Martin (New Haven, Conn.:

Yale University Press, 2011), 334.

${ }^{4}$ Paula Day, "Foreword: Lucienne at Home and in the Garden," in Casey, Lucienne Day, 8.
} 
By the mid-1970s, with several of her contacts in the textile industry retiring and consumer tastes shifting, Day focused on developing patchwork silk wallhangings. But in telling the story of her new work, she called them "silk mosaics," distancing them from craft and needlework. "I'm a designer,' she insisted, 'not a maker. I employ others to make the mosaics. I am an artistdesigner." "W While an artist's choice of terminology to describe their own work should be respected, scholars have since maintained and reinforced Day's distinction to the point of obscuring - or even denying - that the silk mosaics, by whatever name, were created through a patchwork process. In her monograph on Day and her husband Robin Day, Lesley Jackson argues, "the word 'mosaic' stressed correspondence with architecture rather than textiles, and thus highlighted the associations with interior design." ${ }^{\text {In }}$ fact, the particular patchwork technique Day employed, known in the U.S. as English paper piecing, is often called mosaic patchwork in Britain. And we need no reference to Roman mosaics to link the concept with interior design; various forms of textiles have, after all, been used as decorative or functional wall coverings throughout history. In further detailing how these pieces were constructed, Jackson categorically rejects any point of comparison with patchwork:

Her silk mosaics were constructed from small squares or rectangles of coloured silk, sewn together, then supported on a stiffer fabric backing. This technique differed in several key respects from patchwork, notably in the shape of the elements (all created on a $1 \mathrm{~cm}[0.4 \mathrm{in}]$ module), the choice of fabric (plain silks rather than printed cottons), and the fact that paper templates were not removed from the work. ${ }^{7}$

Perhaps Jackson was thinking of the hexagons, diamonds, and other shapes common to historical examples of English patchwork, but square- and rectangle-based patchwork are well represented in this history too, nor would a technical definition of patchwork as joining patches of fabric to one another exclude patches of a particular shape. Printed cottons are certainly the preferred material for the American patchwork quilts that have more recently influenced perceptions of what patchwork is, but patchwork made with silk is also not terribly unusual, especially in Britain. ${ }^{8}$ Closer to the period in which Day worked, British how-to books on patchwork from the 1960 s and '70s continued to recommend silk as a suitable material and show many examples of its use. ${ }^{9}$ While it's true that today's patchworkers typically remove the papers before backing the finished piece, many historical examples have been found with papers, sometimes cut from newsprint, left in. Jackson has more to say:

\footnotetext{
5 J. Glancey, "Style: Adding Colour to a Material World: Lucienne Day's Designs Brightened Britain in the Fifties," The Independent, April 24, 1993; quoted in Casey, Lucienne Day, 108.

6 Jackson, Robin \& Lucienne Day, 160.

7 Jackson, 160.

${ }^{8}$ One of the earliest surviving pieces of British patchwork, dated to 1718 , was created entirely in silk, which was not unusual. Some templates remain in place to this day. See e.g., Susan Briscoe, The 1718 Coverlet: 68 Quilt Blocks from the Oldest Dated British Patchwork Coverlet (Blue Ash, Ohio: David \& Charles, 2014); "1718 Coverlet," The Quilters' Guild Collection, accessed January 27, 2021, https://www.quiltmuseum.org.uk/collections/heritage/1718coverlet.html.

${ }^{9}$ E.g., Alice Timmins, Introducing Patchwork (London: B. T. Batsford, 1968); Alice Timmins, Patchwork Simplified, American edition (New York: Arco, 1973).
} 
Also significant was the non-utilitarian nature of the finished hangings, conceived as works of art rather than coverings for domestic objects. In this way Lucienne made a decisive break . . . from the conventions of domestic handicraft traditions. ${ }^{10}$

As already noted, Day did not shun such domestic craft as knitting, sewing, and patchwork. Although she sought to distance her mosaics from these tasks, it was her skill with a needle that enabled their construction. ${ }^{11}$ Even their conception came from needlework: the idea for the silk mosaics came when a visitor to her studio compared her commissioned design for fire shutters to embroidery. ${ }^{12}$ Day soon passed the actual sewing duties to assistants, including her niece, freeing herself to focus on design. As much as it was practical, this division of labor was meaningful: as quoted above, she was the artist-designer, employing others to sew.

Day's reluctance to be identified with "making," after a much-lauded career as a working designer, reflects what Elissa Auther has described as "fiber's presumed place in the design world and its historical marginalization as decoration, women's work, or mere craft." 13 In sharing her silk mosaics with the public, Day sought "an art gallery atmosphere rather than a craftsmen atmosphere," 14 and indeed they were exhibited at prominent venues including Britain's National Theatre and the Queen Elizabeth II Conference Centre. Representative pieces are now held by the Victoria and Albert Museum and the Art Institute of Chicago, among others.

Day was by no means alone in resisting the notion that textile art was allied with or derived from craft. By the 1960s, another generation of art students - especially in the United States-were turning to textiles as a medium, and they too struggled to gain recognition for textiles as a legitimate medium for artistic expression. ${ }^{15}$ Unfortunately, one effect of resisting the association with craft is that Day's silk mosaics have not been considered alongside comparable needlework in Britain, such as patchwork by Iona Dorrington ${ }^{16}$ or examples shown in practical books by Alice Timmins. ${ }^{17}$ Were Day's use of patchwork more acknowledged, her mosaics could also be fruitfully viewed in comparison and contrast with the simultaneously developing studio art quilt movement in America, wherein artists (often formally trained) sought to legitimize patchwork and quiltmaking as an art form. ${ }^{18}$ Looking further ahead, Day's mosaics could be seen as

\footnotetext{
${ }^{10}$ Jackson, Robin \& Lucienne Day, 160.

${ }^{11}$ Note however an early, "quite crudely made" example posted on the Robin and Lucienne Day Foundation's Instagram feed, accessed October 19, 2020, https:/www.instagram.com/p/CEmL4gdJnxA/. The Foundation suggests that "its consciously naive charm reflects her pleasure in experimenting with a new 'craft' medium," in contrast to her resistance to a craft label as generally depicted in the critical literature.

12 Jackson, Robin \& Lucienne Day, 160.

${ }^{13}$ Elissa Auther, "From Design for Production to Off-Loom Sculpture," in Crafting Modernism: Midcentury American Art and Design, ed. Jeannine Falino (New York: Harry N. Abrams, 2011), 144.

14 "Letter by Lucienne Day to Mrs. P. Rosenthal," n.d., Lucienne and Robin Day Archive (AAD/2000/4/15), V\&A Archive of Art and Design; quoted in Casey, Lucienne Day, 108.

15 See Auther, "From Design for Production to Off-Loom Sculpture."

${ }^{16}$ See Constance Howard, Twentieth-Century Embroidery in Great Britain 1964-1977 (London: B. T. Batsford, 1984), fig. 42. Dorrington's piece employs a gridded structure, like Day's mosaics, but with the additional complexity of curves. Howard's thorough study of the period's embroidery, broadly defined, offers much helpful context.

17 Timmins, Introducing Patchwork; Timmins, Patchwork Simplified.

${ }^{18}$ See Sandra Sider, Pioneering Quilt Artists, 1960-1980: A New Direction in American Art (New York: CreateSpace Independent Publishing Platform, 2010); and Eleanor Levie, American Quiltmaking: 1970-2000 (Paducah, Ky.: American Quilter's Society, 2004), especially chap. 6.
} 
anticipating the "modern quilts" of the 2010s; for example, Black Window's color blocking, asymmetry, and emphasis on negative space were thirty years ahead of the modern quilters who would explore the same concepts. ${ }^{19}$

While Haraszty faced similar challenges moving from design for industry to craft, she responded quite differently. First, she approached craft from a different venue: craft was enjoying a popular revival alongside the professional reassessment of craft media and methods, and Haraszty's embroidery designs for kits and books catered to this trend. Despite her "childhood memories of needlework fiascos," ${ }^{20}$ Haraszty became an enthusiastic, exuberant, and evangelistic embroiderer, working frequently in motifs of poppies and other flowers from her garden. "I think of myself as a Designer by profession, an Embroiderer by chance, and an incurable Gardener by compulsion." 21 Day shared this passion for gardening as well as the primary assertion of being a design professional, but Haraszty felt that embracing her role as a craftsperson was not something that threatened her standing as a professional.

Of course, the biases were real. Of Haraszty's book Needlepainting, one obituary writer described its eponymous technique dismissively as "probably something people do in Hungary." 22 In fact, her childhood experiences of embroidery, quite entertainingly outlined in the book, make clear that needlepainting was in fact nothing like the regimented embroidery taught in 1920s Hungary. Haraszty used "needlepainting" to instead describe a free-wheeling approach using a limited number of stitches with an unlimited array of yarns, packed and piled together to create a highly textured surface. Like Day, Haraszty found the standard language of craft insufficient to encompass her methods. But while Day insisted on setting her work outside of and opposed to craft work, Haraszty clearly viewed needlepainting as a type of embroidery, a subset within the discipline that offered her an avenue to embrace a craft she had previously rejected. Nevertheless, while Day's silk mosaics merit at least a section in the main monographs, Haraszty's embroidery story is told in her own words, in her own books, and otherwise hidden behind designer bios that note simply that after leaving Knoll, "her lifestyle and aesthetic shifted dramatically [when] she began to focus on handwork and embroidery," 23 dying in "relative obscurity". 24

Compared to the rigid geometric structure of Day's silk mosaics, Haraszty's embroidery is freeform and even a little chaotic. This approach appealed to her greatly. It's tempting to view Day's craft work as the more serious and professional of the two, given her attitude and the restrained, structural nature of the work. In the literal sense of the word, though, Haraszty was just as much a professional in her embroidery work. While Day's wall pieces were made on commission, Haraszty's embroidery designs were commissioned and sold as kits (in addition to her books). The markets were very different, with Day selling in gallery shows whereas Haraszty

\footnotetext{
${ }^{19}$ For images of Black Window and other silk mosaics, see "Lucienne Day's Silk Mosaics," Victoria and Albert Museum, accessed January 26, 2020, https://www.vam.ac.uk/articles/lucienne-days-silk-mosaics. Some characteristics often considered definitive to "modern quilts" are listed at "What Is Modern Quilting?," The Modern Quilt Guild, accessed January 27, 2021, https://www.themodernquiltguild.com/modern-quilting.

${ }^{20}$ Haraszty and Colen, Needlepainting: A Garden of Stitches, 3.

${ }^{21}$ Haraszty and Colen, 4.

${ }^{22}$ Peter Blake, "Eszter," Interior Design, February 1995, Gale Academic OneFile (GALE|A16663252).

${ }^{23}$ Nurit Einik, "Haraszty, Eszter," in Falino, Crafting Modernism, 284-85.

${ }^{24}$ Martin, "Eszter Haraszty."
} 
designed patterns and kits aimed at home embroiderers, thus showing two professional approaches to blending craft and design at a time when the very meaning of those terms - and of their status as professional pursuits - were under intense scrutiny and debate.

Glenn Adamson describes the shifting professional attitudes toward craft between the Second World War and 1970 as a "reorientation of craft away from design and toward gallery-based art," with the dominant model of the "designer-craftsman," allied with industry, giving way to the "artist-craftsman," more concerned with expression. ${ }^{25}$ Day's and Haraszty's careers, overlaid on this period, could each be viewed as a manifestation of this trajectory, beginning with their work as designers within the textile industry and moving into more personally expressive textile pursuits. With the silk mosaics, Day, of course, positioned herself far closer to the artistcraftsperson model (though, pointedly, she used the term "artist-designer"), exhibiting in galleries in a way that was becoming more and more the norm. She noted, "It was a big step to take from designs which were comparatively inexpensive, and made in hundreds of yards, to the very elitist one-offs. . . . But I felt that I had done that [kind of work] an awfully long time, and why couldn't I please myself for a bit?" ${ }^{26}$ Her new work, in other words, was for personal enjoyment and expression of her creativity, quite in line with the American crafters displaying their own artistic work in galleries.

Haraszty, though, found her place not in the gallery but on the other side of a quandary in the studio craft movement's institutionalization: the distinction between the handicraft of the professional and the homecraft of the amateur - the latter exactly the sort of domestic association Day sought to avoid. But Haraszty's embroidery, made to furnish her own home, was unquestionably domestic. Nevertheless, she too could be seen as an artist-craftsperson, with selfexpression as a primary value. One can hardly read Needlepainting (or her obituaries) without recognizing that her wild, over-the-top designs were very much expressive of the person who stitched them.

Adamson is careful to note the divergent attitudes amid the decades-long institutionalization process; within the broader trends, there were of course differences of opinion. Day and Haraszty may not have been on the same page in regard to the stories they wanted their craft work to tell professionally, but perhaps more than any other craft, needlework carries with it a gendered weight that must be considered alongside the context of professionalism. As we've already seen, Day was concerned to separate her mosaics from a domestic sphere that cast a shadow over anything created with a needle, and Haraszty's early aversion to embroidery came at least in part from its enforcement of a kind of femininity she wasn't eager to embrace. As Rozsika Parker notes in The Subversive Stitch, "When women embroider, it is seen not as art, but entirely as the expression of femininity. And, crucially, it is categorised as craft." ${ }^{27}$ As the studio craft movement debated the relative merits and definitions of craft, design, and art, practitioners of embroidery and other needle arts also had to contend with these additional stereotypes attached to their work, and the centuries of history behind them. In this context, it is quite easy to

\footnotetext{
${ }^{25}$ Glenn Adamson, "Gatherings: Creating the Studio Craft Movement," in Falino, Crafting Modernism, 41.

${ }^{26}$ From interview by S. Mansfield, "Something Completely Different," The Scotsman, April 4, 2003; quoted in Casey, Lucienne Day, 113.

${ }^{27}$ Rozsika Parker, The Subversive Stitch: Embroidery and the Making of the Feminine, new edition (London: I.B. Tauris, 2010), 5 .
} 
understand why a successful designer like Day would be cautious about unequivocally embracing a craft label that could undermine perceptions of her substantial achievements. But The Subversive Stitch offers a lens that allows us to reconcile Day's skepticism of craft and Haraszty's enthusiastic embrace of the needle: "the dual face of embroidery. . . . [which] has provided both a weapon of resistance for women and functioned as a source of constraint. It has promoted submission to the norms of feminine obedience and offered both psychological and practical means to independence." ${ }^{28}$ Day's and Haraszty's positions, then, are not in conflict, but rather reflective of a duality inherent in the cultural contexts of needlework, that it may both oppress and empower. As Parker notes, there is a tendency to view art created by women as homogenous; we should instead view the varied attitudes of Day and Haraszty as a reminder that they lived two different human lives, each with independent agency to tell their own stories about design and craft. These stories are only made richer by comparison and contrast, where differences and similarities can bring otherwise hidden stories into view.

\section{Bibliography}

Adamson, Glenn. “Gatherings: Creating the Studio Craft Movement.” In Falino, Crafting Modernism, 32-55.

Auther, Elissa. "From Design for Production to Off-Loom Sculpture.” In Falino, Crafting Modernism, 144-63.

Blake, Peter. "Eszter.” Interior Design, February 1995, 29-30. Gale Academic OneFile (GALE|A16663252).

Briscoe, Susan. The 1718 Coverlet: 68 Quilt Blocks from the Oldest Dated British Patchwork Coverlet. Blue Ash, Ohio: David \& Charles, 2014.

Casey, Andrew. Lucienne Day: In the Spirit of the Age. Woodbridge, Suffolk: Antique Collectors' Club, 2014.

Day, Paula. "Foreword: Lucienne at Home and in the Garden." In Casey, Lucienne Day, 8-9.

Einik, Nurit. "Haraszty, Eszter.” In Falino, Crafting Modernism, 284-85.

Falino, Jeannine, ed. Crafting Modernism: Midcentury American Art and Design. New York: Harry N. Abrams, 2011.

Haraszty, Eszter, and Bruce David Colen. Needlepainting: A Garden of Stitches. New York: Liveright, 1974.

Howard, Constance. Twentieth-Century Embroidery in Great Britain 1964-1977. London: B. T. Batsford, 1984.

Jackson, Lesley. Robin \& Lucienne Day: Pioneers of Modern Design. New York: Princeton Architectural Press, 2001.

Levie, Eleanor. American Quiltmaking: 1970-2000. Paducah, Ky.: American Quilter's Society, 2004.

Martin, Earl. "Eszter Haraszty (1920-1994).” In Knoll Textiles, 1945-2010, edited by Earl Martin, 334-38. New Haven, Conn.: Yale University Press, 2011.

Modern Quilt Guild. “What Is Modern Quilting?” Accessed January 27, 2021. https://www.themodernquiltguild.com/modern-quilting.

Parker, Rozsika. The Subversive Stitch: Embroidery and the Making of the Feminine. New edition. London: I.B. Tauris, 2010.

\footnotetext{
${ }^{28}$ Parker, xix.
} 
Robin and Lucienne Day Foundation Instagram post, accessed October 19, 2020, https://www.instagram.com/p/CEmL4gdJnxA/.

Quilters' Guild Collection. “1718 Coverlet.” Accessed January 27, 2021. https://www.quiltmuseum.org.uk/collections/heritage/1718-coverlet.html.

Sider, Sandra. Pioneering Quilt Artists, 1960-1980: A New Direction in American Art. New York: CreateSpace Independent Publishing Platform, 2010.

Timmins, Alice. Introducing Patchwork. London: B. T. Batsford, 1968. . Patchwork Simplified. American edition. New York: Arco, 1973.

Victoria and Albert Museum. “Lucienne Day’s Silk Mosaics.” Accessed January 26, 2020. https://www.vam.ac.uk/articles/lucienne-days-silk-mosaics. 